Turk J Cardiovasc Nurs 2019;10(23):122-128

\title{
Hipertansiyon Hastalarının İlaç Uyum Düzeyleri İle Spirütüel İyi Oluşları Arasındaki İlişkinin Belirlenmesi
}

\author{
Güler Duru Aşiret, ${ }^{1}$ (1) Cansu Okatan² \\ ${ }^{1}$ Aksaray Üniversitesi Sağlık Bilimleri Fakültesi, Hemşirelik Bölümü, İç Hastalıkları Hemşireliği Anabilim Dalı, Aksaray \\ ${ }^{2}$ Aksaray Üniversitesi Sağlık Bilimleri Fakültesi, Hemşirelik Bölümü, Aksaray
}

\begin{abstract}
Özet
Amaç: Bu araştırma, hipertansiyon hastalarının tedaviye uyum düzeyi ile spirütüel iyi oluşları arasındaki ilişkinin belirlenmesi amacıyla yapılmıştır.

Yöntemler: Araştırma, Aralık 2018-Mayıs 2019 tarihleri arasında bir eğitim araştırma hastanesinin dahili kliniklerinde yatarak tedavi gören, en az 6 ay önce hipertansiyon tanısı almış ve çalışmaya katılmaya gönüllü 228 hasta ile yapıldı. Araştırmanın verileri hastaların sosyodemografik özellikleri ve hastalığa ilişkin özelliklerinin tanıtılığı tanıtıcı bilgi formu, İlaç Tedavisine Bağlılık/Uyum Öz-Etkililik Ölçeği Kısa Formu ve Spiritüel İyi Oluş Ölçeği kullanılarak araştırmacılar tarafından yüz yüze görüşme yöntemiyle toplandı. Verilerin istatistiksel değerlendirmesinde sayı, yüzde, ortalama, standart sapma, Kruskall Wallis analizi ve Spearman korelasyon testi kullanıldı.

Bulgular: Çalışma kapsamındaki hipertansiyon hastalarının İlaç Tedavisine Bağlılık/Uyum Öz-Etkililik Ölçeği Kısa Formu

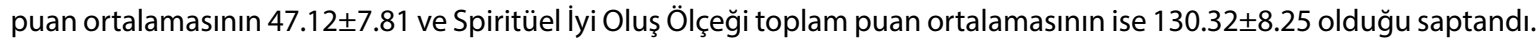
Çalışma kapsamındaki bireylerin İlaç Tedavisine Bağlılık/Uyum Öz-Etkililik Ölçeği Kısa Formu ve Spiritüel İyi Oluş Ölçeği'den aldıkları puanların ortalamaları arasındaki ilişki incelediğinde; iki ölçek toplam puan ortalaması arasında pozitif yönde bir ilişki olduğu belirlenmiştir ( $r=0.198, p=0.003)$.

Sonuç: Çalışma kapsamındaki hipertansiyon hastalarının ilaç uyumunun ve spiritüel iyilik halinin yüksek düzeyde olduğu belirlendi. Hastaların spiritüel iyilik hali düzeyi arttıkça ilaç uyumlarının da arttığı belirlendi.
\end{abstract}

Anahtar sözcükler: Hipertansiyon; ilaç; spiritüel; uyum.

Determination of the Relationship between Drug Compliance Levels and Spiritual WellBeing of Hypertension Patients

\footnotetext{
Abstract

Objective: The aim of this study was to determine the relationship between treatment compliance and spiral well-being of hypertensive patients.

Methods: The study was conducted between December 2018 and May 2019 with 228 patients who were hospitalized in the internal clinics of a training research hospital, diagnosed with hypertension at least 6 months ago and volunteered to participate in the study. The data of the study were collected by face-to-face interviews by using the descriptive information form, sociodemographic characteristics of the patients and the characteristics of the disease, the Medication Adherence
}

\footnotetext{
İletişim (Correspondence): Dr. Güler Duru Aşiret. Aksaray Üniversitesi Sağlık Bilimleri Fakültesi, Hemşirelik Bölümü, Iç Hastalıkları Hemşireliği Anabilim Dalı Aksaray, Turkey

Telefon (Phone): +90 3822882768 E-Posta (E-mail): gulerduru@gmail.com

Başvuru Tarihi (Submitted Date): 19.09.2019 Kabul Tarihi (Accepted Date): 06.12.2019
} 
Self-Efficacy Scale-Short Form in hypertensive patients and Spiritual Well-Being Scale. The study was conducted between December 2018 and May 2019 with 228 patients who were hospitalized in the internal clinics of a training research hospital, diagnosed with hypertension at least 6 months ago and volunteered to participate in the study. Number, percentage, mean, standard deviation, Kruskall Wallis analysis and Spearman correlation test were used for statistical evaluation of the data.

Results: It was found that the mean scores of the Medication Adherence Self-Efficacy Scale-Short Form in hypertensive patients were $47.12 \pm 7.81$ and the mean total score of the Spiritual Well-Being Scale was $130.32 \pm 8.25$. When the relationship between the mean scores of the scores obtained from the Medication Adherence Self-Efficacy Scale-Short Form in hypertensive patients and Spiritual Well-Being Scale was examined; there was a positive relationship between two scales total score mean ( $r=0.198, p=0.003)$.

Conclusion: It was determined that drug compliance and spiritual well-being of hypertension patients in the study were high. It was determined that as the level of spiritual well-being of patients increased, drug compliance increased.

Keywords: Compliance; drug; hypertension; spiritual.

Cite this article as: Aşiret GD, Okatan C. Determination of the Relationship Between Drug Compliance Levels and Spiritual Well-Being of Hypertension Patients. Turk J Cardiovasc Nurs 2019;10(23):122-128.

G elişmiş ve gelişmekte olan ülkelerin başta gelen sağlık sorunları arasında yer alan hipertansiyon, önlenebilir ölüm nedenleri içerisinde ilk sırada yer almakta ve tedavi edilmediğinde kalp yetersizliği, miyokard infarktüsü, böbrek yetersizliği, inme, görme kaybı gibi pek çok hastalığa neden olabilmektedir. ${ }^{[1]}$ Hipertansiyona bağlı ortaya çıkabilecek hastalıklar göz önüne alındığında, hastalık yönetimi önem arz etmektedir. Başarılı hipertansiyon yönetimi hastanın, kendi kan basıncı kontrolünü sağlaması ve izlemesi, önerilen yaşam biçimi değişikliklerini dikkate alması ve davranışa dönüştürmesi ile mümkün olabilmektedir.

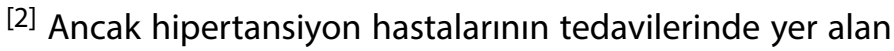
antihipertansif ilaçların kullanımı sırasında ve özellikle de yaşam tarzı değişikliklerini uygularken hasta uyumsuzluğunun sık görüldüğü belirtilmektedir. Hastaların yarısının tedavinin ilk yılında tedaviyi bıraktığı ve yaklaşık \%10'unun ise gün içinde ilaçlarını almayı unuttuğu bildirilmektedir. [3] Dünya Sağlık Örgütü hipertansiyon hastalarının antihipertansif ilaç uyum düzeylerinin $\% 50$ oranında olduğunu tahmin etmektedir. ${ }^{[1]}$ Ülkemizde de durum çok farklı olmamakla birlikte 2012 yılında yapılan hipertansiyon prevalans çalışması sonuçlarına göre antihipertansif ilaç kullanım oranı \%47.5 olduğu belirlenmiştir. ${ }^{[4]}$ Kan basıncının kontrol altına alınmasında tedaviye uyum önemli bir faktördür. Hastaların planlanmış tedaviye uymaması, hipertansiyon kontrolünde önemli bir engel olup, morbidite ve ölüme neden olmakta ve yılda yaklaşık 100 milyar dolar tutarında maliyet doğurduğu tahmin edilmektedir. ${ }^{[5]}$

Hastalar tedaviye uyumda birçok faktörden etkilenebilmektedir. Dünya Sağlık Örgütü, tedaviye uyumda etkili olan bu faktörleri; sosyoekonomik faktörler, sağlık ekibi ve sağlık sistemi ile ilişkili faktörler, hastalıkla ilgili faktörler, tedaviyle ilgili faktörler ve hastayla ilişkili faktörler olmak üzere beş başlık altında incelemiştir. Hipertansif hastaların tedaviye uyumlarında etkili olan faktörlerden biri de spiritüalitedir. ${ }^{[1]}$
Spiritüalite, bireyin kendisi ve diğer insanlarla ilişkilerini, evrendeki yerini, yaşamın anlamını kavraması ve kabul etme çabası şeklinde tanımlanmaktadır. Aynı zamanda yaşam boyu kazanılan bilgilerin de bir sonucudur. Bu nedenle bireylerin hastalığa ve tedaviye uyum sürecinde fiziksel, duygusal, sosyal yönü kadar önemli olan spiritüel yönü de önem taşımaktadır. ${ }^{[6]}$ Literatürde spiritüalite ile hipertansiyon arasındaki ilişkiyi inceleyen pek çok çalışmaya rastlanmaktadır. Amerika'da yaşayan Afrikalı kadınlar ile yapılan bir araştırmada spirütüel başa çıkma ile hipertansiyon riskinde azalmanın ilişkili olduğu saptanmıştır. ${ }^{[7]}$ Budist yetişkin bireyler ile yapılan bir çalışmada dinsel aktivitelere katılmanın hipertansiyondan koruyucu rolünün olduğu bildirilmiştir. ${ }^{[8]}$ Literatür incelendiğinde spiritualite ile hipertansif hastaların ilaç uyumu arasındaki ilişkiyi inceleyen sınırlı sayıda çalışmaya rastlanmıştır. Kretchy ve arkadaşlarının yaptığı çalışmada maneviyatı yüksek olan hipertansiyon hastalarının, maneviyat ile sağlık arasındaki ilişkiye daha az önem veren hastalara göre düşük ilaç uyumunun 2.68 kat daha fazla olduğu belirlenmiştir. ${ }^{[9]}$ Abel ve Greer'in çalışmasında da spiritüalite ile ilaç uyumu arasında bir ilişkinin olmadığı belirlenmiştir. ${ }^{[10]}$

Bütüncül bakım veren hemşirelerin, hastaların tüm özelliklerini dikkate alarak bakımlarını ve eğitimlerini planlamaları belirledikleri hedefe ulaşmalarında onlara kolaylık sağlayacaktır. Bu doğrultuda hemşirelerin hipertansiyon hastalarına yönelik bütüncül bir bakım vermek için bakım planı geliştirirken hastaların manevi boyutunu da göz önünde bulundurması önem arz etmektedir. ${ }^{[11]}$ Hemşireler, hipertansiyon hakkında hasta ve ailesine bilgi verirken, hastaları kan basıncını düzenli izlemeleri konusunda teşvik ederken, hastanın her kontrole geldiğinde ilaç tedavisi ve nonfarmakolojik tedavisini değerlendirirken, hastayı ilaç ve yaşam değişikliklerine uyum sağlaması konusunda cesaretlendirirken hastaların spiritüel yönünü de göz önüne almalıdır. ${ }^{[12]}$ 


\section{Gereç ve Yöntem}

Araştırmanın Amacı: Tanımlayıcı nitelikteki bu araştırma hipertansiyon hastalarının ilaç uyum düzeyleri ile spirütüel iyi oluşları arasındaki ilişkiyi belirlemek amacıyla yapılmıştır. Bu araştırmada hipertansiyon hastalarının ilaç uyumu ve spirütüel iyi oluş düzeyleri nasıldır ve ilaç uyum düzeyleri ile spirütüel iyi oluşları arasında ilişki var mıdır sorularına yanıt aranmıştır.

Araştırmanın Evreni ve Örneklemi: Araştırma Aralık 2018-Mayıs 2019 tarihleri arasında İç Anadolu Bölgesi'nde bir eğitim ve araştırma hastanesinin dahili kliniklerinde (iç hastalıkları, göğüs hastalıkları, kardiyoloji ve nöroloji) yatarak tedavi gören, hipertansiyon tanısı alan 228 hasta ile yürütülmüştür. Çalışmada herhangi bir örnekleme yöntemi kullanılmamıştır. Araştırmaya araştırmanın yapıldığı süre içerisinde araştırmanın yürütüldüğü kliniklerde yatarak tedavi gören, en az 6 ay önce hipertansiyon tanısı almış, en az bir tane antihipertansif ilaç kullanan, araştırmanın amacı hakkında bilgilendirilen ve araştırmaya katılmayı kabul eden hastalar dahil edilmiştir.

\section{Veri Toplama Yöntem ve Araçları}

Araştırma verilerinin toplanmasında, Tanıtıc Bilgi Formu, İlaç Tedavisine Bağlııı/ Uyum Öz-Etkililik Ölçeği Kısa Formu ve Spiritüel İyi Oluş Ölçeği kullanılmıştır. Araştırmanın verileri araştırmacılar tarafından yüz yüze görüşme tekniği ile yaklaşık 15-20 dakika sürede hasta odasında toplanmıştır.

Tanıtıcı Bilgi Formu: Literatürdeki çalışmalar incelenerek geliştirilmiştir. ${ }^{[9,10,12-18]}$ Bu form hipertansif bireylerin sosyo-demografik özelliklerini belirleyen yaş, cinsiyet, medeni durum, eğitim düzeyi, çalışma durumu ve ekonomik durum algısı, dini ve dini aktivitelerini içeren sekiz; hipertansiyona eşlik eden kronik hastalık durumu, hipertansiyon tanısı alma ve antihipertansif ilaç kullanım süresi, günlük kullanılan antihipertansif ilaç sayısı, son altı ayda hipertansiyon nedeni ile acile başvurma durumu, en son kontrole gitme zamanı ve hipertansiyona ilişkin bilgi alma durumunu belirleyen yedi soru olmak üzere toplam 15 sorudan oluşmuştur.

\section{İlaç Tedavisine Bağlılık/ Uyum Öz-Etkililik Ölçeği Kısa} Formu (IBÖS-KF): Hipertansiyonu olan bireylerin ilaç uyum düzeylerini belirlemek amacıyla İlaç Tedavisine Bağlılık/ Uyum Öz-Etkililik Ölçeği Kısa Formu (IBÖS-KF) kullanılmıştır. Ölçek Ogedegbe ve ark. (2003) tarafından hipertansiyon hastalarının ilaç uyumunu değerlendirmek amacıyla geliştirilmiştir. ${ }^{[19]}$ Türkiye'de geçerlik ve güvenirliği Hacıhasanoğlu ve arkadaşları tarafından 2012 yılında yapılmıştır. [20] Ölçek 13 maddeden oluşmakta ve dörtlü likert tipindedir. Ölçekten en düşük 13 puan ve en yüksek 52 puan alınabil- mektedir. Ölçek puanındaki artış, bireylerin antihipertansif ilaç tedavisine uyumlarının iyi düzeyde olduğunu göstermektedir. Ölçeğin Cronbach Alpha katsayısı 0.92'dir. ${ }^{[20]} \mathrm{Bu}$ çalışmada belirlenen Cronbach Alpha katsayısı 0.92'dir.

Spiritüel İyi Oluş Ölçeği (SiOÖ): Hipertansiyon hastalarının spiritüel iyilik düzeylerini belirlemede Spiritüel İyi Oluş Ölçeği (SiOÖ) kullanılmıştır. Ölçek Ekşi ve Kargaş tarafından (2017) geliştirilmiştir. ${ }^{[21]}$ Ölçek 29 maddeden oluşmakta ve beşli likert tipindedir. Ölçekte yer alan yedi soru $(3,7,11,15$, 19, 23 ve 26) ters kodlanmaktadır. Ölçekten alınacak puan aralığı 29-145 arasında değişmektedir. Ölçekten alınan puan arttıkça spiritüel iyi oluş düzeyi artmaktadır. Ölçeğin Cronbach alpha katsayısı 0.886 'dır. ${ }^{[21]}$ Bu çalışmada belirlenen Cronbach Alpha katsayısı 0.76 'dır.

Araştırma Verilerinin Değerlendirilmesi: Araştırmanın veriler SPSS 21.0 paket program ile değerlendirilmiştir. Verilerin normal dağılıma uygunluğu Tek Örneklem Kolmogorov Smirnov analizi ile test edilmiştir. Araştırma kapsamındaki bireylerin tanımlayıcı özellikleri sayı, yüzde, ortalama ve standart sapma kullanılarak özetlenmiştir. iki gruplu değişkenlerin skorlarını karşılaştırmada Mann Whitney U testi ve üç ya da daha fazla gruplu değişkenlerin skorlarını karşılaştırmada Kruskal Wallis testi kullanılmıştır. Ölçek toplam puanlarının birbiri ilişkisi Spearman korelasyon testi kullanarak analiz edilmiştir. $\mathrm{P}<0.05$ değeri istatistiksel anlamlılık sınırı olarak kabul edilmiştir.

Araştırmanın Etik Boyutu: Bu araştırma Helsinki Bildirgesi ilkelerine uygun olarak gerçekleştirilmiştir. Araştırmaya başlamadan önce Aksaray Üniversitesi İnsan Araştırmaları Etik Kurul'undan (2019/36) ve araştırmanın yürütüldüğü kurumdan yazılı izin alınmıştır. Çalışmaya katılımda gönüllülük esas alınmıştır. Araştırma kapsamındaki hastalara araştırmacılar tarafından araştırmanın amacı hakkında bilgi verilmiş ve bilgilendirilmiş olurları alınmıştır. Hipertansiyon hastalarının çalışmaya katılmama kararının, onlara uygulanan hemşirelik girişimlerini etkilemeyeceği ve herhangi bir zamanda çalışmadan çekilebileceği bilgisi de verilmiştir.

\section{Bulgular}

Çalışma kapsamındaki hipertansiyon hastalarının yaş orta-

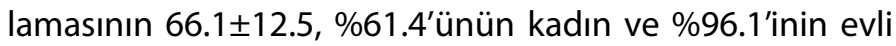
olduğu belirlenmiş̧ir. Hastaların \%54.8'nin ilköğretim mezunu olduğu, \%94.3'ünün şu an herhangi bir işte çalışmadığı ve \%79.4'ünün ekonomik durumunun orta seviyede olduğu saptanmıştır (Tablo 1).

Bireylerin \%86.4'ünün hipertansiyona ek en az bir kronik hastalığının olduğu, \%61.8'inin hipertansiyon tanısı alma süresinin 10 yıldan daha kısa olduğu tespit edilmiştir. Ayrıca 


\begin{tabular}{lcc}
\multicolumn{3}{l}{ Tablo 1. Hastaların demografik özelliklerinin dağılımı $(\mathrm{n}=228)$} \\
\hline Tanımlayıcı özellikler & $\mathbf{n}$ & $\%$ \\
\hline Yaş (yıl) $(66.1 \pm 12.5)$ & & \\
$\quad 64$ yaş ve altı & 97 & 42.5 \\
$\quad 65$ yaş ve üzeri & 131 & 52.5 \\
Cinsiyet & & \\
$\quad$ Kadın & 140 & 61.4 \\
Erkek & 88 & 38.6 \\
Medeni durum & & \\
$\quad$ Evli & 219 & 96.1 \\
Bekar & 9 & 3.9 \\
Eğitim durumu & & \\
$\quad$ Okuryazar değil & 87 & 38.2 \\
Ilköğretim & 125 & 54.8 \\
Lise ve üzeri & 16 & 7.0 \\
Şuan çalışma durumu & & \\
Çalışıor & 13 & 5.7 \\
$\quad$ Çalışmıyor & 215 & 94.3 \\
Gelir durumunu & & 10.5 \\
lyyi & 24 & 79.4 \\
Orta & 181 & 10.1 \\
Kötü & 23 & \\
\hline
\end{tabular}

bireylerin tamamına yakını (\%86.4) bir tane antihipertansif ilaç kullandığını, \%31.1'i son bir yıl içinde hipertansiyon nedeniyle acil servise başvurduğunu ve \%93.4'ü düzenli doktor kontrolüne gittiğini ifade etmiştir (Tablo 2).

Tablo 3'te hasta bireylerin IBÖS-KF ve SiOÖ'nin toplam puan ortalamaları yer almaktadır. Çalışma kapsamındaki hipertansiyon hastalarının ölçek toplam puan ortalamaları incelendiğinde. IBÖS-KF puan ortalamasının 47.12 \pm 7.81 ve SiOÖ toplam puan ortalamasının ise $130.32 \pm 8.25$ olduğu saptanmıştır. Çalışma kapsamındaki bireylerin her iki ölçekten aldıkları puanların ortalamasının yüksek olduğu görülmektedir. Bu bulguya göre hipertansiyon hastalarının ilaç uyumunun ve spiritüel iyilik halinin yüksek düzeyde olduğu belirlenmiştir.

Çalışma kapsamındaki hipertansiyon hastalarının bazı tanımlayıcı özellikleri ile IBÖS-KF and SiOÖ toplam puan ortalamalarının karşılaştırılması Tablo 4'te yer almaktadır. Bireylerin cinsiyet, hipertansiyon tanısı alma süresi, son bir yıl içinde acil servise başvuru durumu, kullandığı antihipertansif ilaç sayısı ve hipertansiyon ile ilgili eğitim alma durumları arasında istatistiksel olarak anlamlı bir farklııı̆ın olmadığı belirlenmiştir ( $p>0.05$ ). Bireylerin tanımlayıcı özellikleri ile SiOÖ toplam puan ortalaması karşılaştırıldığında; 65 yaşından küçük, bekar, lise ve üzeri eğitimli olan ve hipertansiyona ek kronik hastalığa sahip olmayan bireylerin SioÖ toplam puan ortalaması istatistiksel olarak anlamlı derecede yüksek olduğu saptanmıştır $(p<0.05)$.

\begin{tabular}{|c|c|c|}
\hline Tanımlayıcı özellikler & $\mathbf{n}$ & $\%$ \\
\hline \multicolumn{3}{|c|}{ Ek kronik hastalığa sahip olma durumu } \\
\hline Evet & 197 & 86.4 \\
\hline Hayır & 31 & 13.6 \\
\hline \multicolumn{3}{|c|}{ Hipertansiyon tanısı alma süresi/yıl (10.6 \pm 6.8$)$} \\
\hline 10 yıl ve altı & 141 & 61.8 \\
\hline 10 yıldan fazla & 87 & 38.2 \\
\hline \multicolumn{3}{|c|}{ 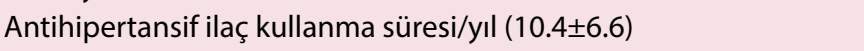 } \\
\hline \multicolumn{3}{|c|}{ Antihipertansif ilaç sayısı $(1.1 \pm 0.3)$} \\
\hline Bir & 197 & 86.4 \\
\hline İki & 30 & 13.2 \\
\hline Üç & 1 & 0.4 \\
\hline \multicolumn{3}{|c|}{$\begin{array}{l}\text { Son bir yıl içinde HT nedeniyle } \\
\text { acil servise başvurma durumu }\end{array}$} \\
\hline Evet & 71 & 31.1 \\
\hline Hayır & 157 & 68.9 \\
\hline \multicolumn{3}{|c|}{ Düzenli doktor kontrolüne gitme durumu } \\
\hline Evet & 213 & 93.4 \\
\hline Hayır & 15 & 6.6 \\
\hline \multicolumn{3}{|c|}{ Hipertansiyon ile ilgili eğitim alma durumu } \\
\hline Evet & 27 & 11.8 \\
\hline Hayır & 201 & 88.2 \\
\hline Toplam & 228 & 100.0 \\
\hline
\end{tabular}

\begin{tabular}{|c|c|c|}
\hline Ölçek & Ort.a \pm SS & Min.-Maks. \\
\hline \multicolumn{3}{|l|}{ İlaç Tedavisine Bağlılık/ Uyum } \\
\hline Öz-Etkililik Ölçeği Kısa Formu & $47.12 \pm 7.81$ & $20-52$ \\
\hline Spiritüel İyi Oluş Ölçeği & $130.32 \pm 8.25$ & $100-145$ \\
\hline
\end{tabular}

Çalışma kapsamındaki bireylerin İÖS-KF ve SiOÖ'den aldıkları puanların ortalamaları arasındaki ilişki incelediğinde; iki ölçek toplam puan ortalamasırarasında pozitif yönde bir ilişki olduğu belirlenmiştir $(r=0.198, p=0.003)$. Hastaların spiritüel iyilik hali düzeyi arttıkça ilaç uyumlarının da arttığı belirlenmiştir (Tablo 5).

\section{Tartışma}

Hipertansiyon gibi kronik hastalıkların tedavisinde karşılaşılan en yaygın sorunlardan birisi ilaç uyum sorunudur. ${ }^{[1]} \mathrm{Bu}$ çalışma hipertansiyon hastalarının ilaç uyum düzeyleri ile spirütüel iyi oluşları arasındaki ilişkiyi belirlemek amacıyla yapıldı. Çalışma sonucunda hastalarının ilaç uyumunun ve spiritüel iyilik hali düzeyinin yüksek olduğu ve spiritüel iyilik hali düzeyi arttıkça ilaç uyumunun da arttığı belirlendi.

Çalışmamızda hipertansiyon hastalarının antihipertansif ilaç uyum düzeyinin iyi düzeyde olduğu görülmektedir. 


\begin{tabular}{|c|c|c|c|c|c|c|}
\hline & \multicolumn{3}{|c|}{ IBÖS-KF } & \multicolumn{3}{|c|}{ sioö } \\
\hline & Ort. \pm SS & Test & $\mathbf{p}$ & Ort. \pm SS & Test & $\mathbf{p}$ \\
\hline \multicolumn{7}{|l|}{ Yaş } \\
\hline 64 yaş ve altı & $48.1 \pm 6.8$ & & & $132.3 \pm 6.5$ & \multirow{2}{*}{-2.753} & \multirow{2}{*}{0.006} \\
\hline 65 yaş ve üzeri & $46.4 \pm 8.4$ & -1.333 & 0.183 & $128.8 \pm 9.6$ & & \\
\hline Erkek & $45.2 \pm 9.3$ & -1.446 & 0.148 & $130.7 \pm 9.1$ & -1.308 & 0.191 \\
\hline \multicolumn{7}{|l|}{ Medeni durum } \\
\hline Evli & $46.9 \pm 7.9$ & & & $130.1 \pm 8.2$ & \multirow{2}{*}{-2.385} & \multirow{2}{*}{0.017} \\
\hline Bekar & $50.8 \pm 1.3$ & -0.976 & 0.329 & $136.5 \pm 6.2$ & & \\
\hline \multicolumn{7}{|l|}{ Eğitim durumu } \\
\hline \multicolumn{7}{|c|}{ Ek kronik hastalığa sahip olma durumu } \\
\hline Evet & $47.1 \pm 7.8$ & & & $129.7 \pm 8.4$ & \multirow{2}{*}{-2.735} & \multirow{2}{*}{0.006} \\
\hline Hayır & $47.1 \pm 7.6$ & -0.011 & 0.991 & $133.8 \pm 5.6$ & & \\
\hline \multicolumn{7}{|l|}{ HT tanısı alma süresi } \\
\hline $10 \leq \mathrm{yll}$ & $47.1 \pm 7.9$ & & & $129.3 \pm 8.6$ & \multirow{2}{*}{-1.757} & \multirow{2}{*}{0.079} \\
\hline$>10 \mathrm{yll}$ & $47.2 \pm 7.5$ & -0.279 & 0.780 & $131.9 \pm 7.3$ & & \\
\hline \multicolumn{7}{|c|}{ Son bir yıl içinde acil servise başvuru durumu } \\
\hline Evet & $48.0 \pm 6.1$ & & & $130.6 \pm 8.5$ & \multirow{2}{*}{-0.347} & \multirow{2}{*}{0.728} \\
\hline Hayır & $46.7 \pm 8.4$ & -0.254 & 0.800 & $130.1 \pm 8.1$ & & \\
\hline \multicolumn{7}{|c|}{ Antihipertansif ilaç sayısı } \\
\hline Bir & $47.1 \pm 8.1$ & & & $130.1 \pm 8.4$ & 1.226 & 0.542 \\
\hline \multicolumn{7}{|c|}{ Hipertansiyon ile ilgili eğitim alma durumu } \\
\hline
\end{tabular}

IBÖS-KF: Ilaç Tedavisine Bağlılık/Uyum Öz-Etkililik Ölçeği Kısa Formu; SiOÖ: Spiritüel lyi Oluş Ölçeği; Ort.: ortalama; SS: standart sapma

Tablo 5. Ölçek toplam puanlarının ilişkisi $(n=228)$
\begin{tabular}{ll} 
Ölçekler & Spiritüel İyi Oluş Ölçeği \\
\hline İlaç Tedavisine Bağlılık/ & \\
Uyum Öz-Etkililik Ölç̧eği & \\
Kısa Formu & \\
r & 0.198 \\
$p$ & $0.003^{*}$ \\
\hline
\end{tabular}

*Önemlilik değerli 0.01 .

Çalışmamızda benzer olarak Vatansever ve ark.'nın ${ }^{[12]}$ ve Tümer ve ark.'nın ${ }^{[15]}$ yaptıkları çalışmalarda da hipertansiyon hastalarının ilaca bağıııı/uyum öz-etkililik puan ortalamalarının iyi düzeyde olduğu saptanmıştır. Asgedom ve ark.'nın ${ }^{[16]}$ çalışmasında hastaların ilaç uyum oranının \%61.8 olduğu bildirilmiştir. Al-Noumani ve ark.'nın ${ }^{[17]}$ yaptığı çalışmada hastalarının ilaç uyum düzeyi \%68 olarak bildirilmiştir. Literatürde hipertansiyon hastalarının ilaç uyumunun düşük olduğunu bildiren çalışmalar da mevcuttur. Kretchy ve ark.'nın ${ }^{[9]}$ çalışmasında hastaların tamamına yakınının (\%93.2) ilaç uyumunun düşük düzeyde olduğu belirlenmiştir. Nguyen ve ark.'nın ${ }^{[18]}$ çalışmasında ise hipertansiyon hastalarının ilaç uyum oranın $\% 49.8$ olduğu saptanmıştır. Vrijens ve ark.'nın ${ }^{[22]} 4783$ hastanın kayıtlarını incelediği bir çalışmada ise hastaların yaklaşık yarısının ilacın reçetelenmesinin ardından bir yıl içinde ilaç kullanmayı bıraktığı tespit edilmiştir. İlaç uyum düzeyinde belirlenen bu farklılı̆ın; bireylerin kişilik, tıbbi ve kültürel özelliklerinin, hastalık süresinin, eğitim alma durumunun ve ilaç uyumunu belirlemede kullanılan ölçüm araçlarının farklıı̆̆ından kaynaklanabileceğini düşünmekteyiz.

Bu çalışmada hipertansiyon hastalarının spiritüel iyilik halinin yüksek düzeyde olduğu belirlenmiştir. Benzer olarak Kretchy ve ark.'nın ${ }^{[9]}$ çalışmasında da hastaların manevi 
ve dine bağlılığının yüksek düzeyde olduğu belirlenmiştir. Abel ve Greer'in çalışmasında da hipertansiyon hastalarının dini aktivitelere katılma ve günlük dua etme oranının yüksek olduğu belirlenmiştir. ${ }^{[10]}$

Sağıı davranışlarını açıklamada maneviyat ve dindarlık gibi sosyal belirleyicilerin sağlık ve tedaviyi etkilemedeki rolü günümüzde giderek daha fazla önem kazanmaktadır. ${ }^{[9]}$ Bireylerin manevi boyutu hastalık ve iyileşme süreci ile etkileşim halindedir. Kanser, kalp hastalıkları, multiple skleroz gibi hastalıklar sadece önemli psikolojik değişikliklere neden olmakla kalmamakta, aynı zamanda hastalıktan ve ölüm olasılığından kaynaklanan manevi sıkıntıyla başedilmesi gerekliliğini de ortaya koymaktadır. Bireyin manevi boyutunun güçlenmesi umudunu ve tedaviye katılımını artırarak iyileşme olasılığını da arttırdığı bildirilmektedir. ${ }^{[23-25]}$ Bu çalışmada hastaların spiritüel iyilik hali düzeyi arttıkça ilaç uyumunun da arttığı belirlenmiştir ( $r=0.198, p=0.003$ ). Bu çalışmadan elde edilen bulgu hipertansiyon hastaları ile yapılan iki çalışma sonucu ile farklılık göstersede farklı hasta grupları ile yapılan çalışma sonuçlarına benzerlik göstermektedir. Kretchy ve ark.'nın ${ }^{[9]}$ çalışmasında hipertansiyon hastalarının düşük ilaç uyum düzeyi ile maneviyat arasında ilişki olduğu bildirilmiştir. Abel ve Greer'in çalışmasında da maneviyat ile ilaç uyumu arasında bir ilişkinin olmadığı berlirlenmiştir. ${ }^{[10]}$ Fakat aynı çalışmada kiliseye daha sık giden kadınların ilaç uyumlarının kiliseye gitmeyenlere göre daha yüksek olduğu belirlenmiştir. Farklı hasta grupları ile yapılan çalışmalarda maneviyat ve ilaç uyumu arasında olumlu bir ilişkinin olduğu bildirilmiştir. Kronik kalp yetersizliği olan hastalar ile yapılan bir çalışmada hastaların maneviyat düzeyi arttıkça ilaç uyumunun da arttığı saptanmıştır. ${ }^{[26]}$ Raghavan ve ark.'nın ${ }^{[27]}$ yaptığı bir çalışmada Hepatit C'li hastaların tedaviye devam etmelerinde dinselliğin önemli bir etken olduğu bildirilmiştir. HIV pozitif hastalar ile yapılan bir sistematik derlemede hastalara uygulanan manevi bakımın tedaviyi kabul etme ve tedaviye uyum üzerine olumlu etkilesinin olduğu bildirilmektedir. ${ }^{[28]}$ Literatürde İslam kültüründe, insanların hastalıkları yönetme konusundaki davranışlarını etkileyebilecek olan, iyileşmenin Tanrı'nın merkezi rolüne inanmakla başladığı bildirilmektedir. Bu inanışa göre, müslümanlar, iyileşmek için Tanrı'ya güvenmekte ve aynı zamanda sağlığı bir hediye olarak görüp sağlıklarını korumanın ve tedaviyi aramanın kendi sorumluluğu olduğuna inanmaktadır. ${ }^{[17,29]}$ Bu nedenle hastaların manevi olarak bir güce inanıp, tedaviye uyum sağlayarak hastalığı en iyi şekilde yönetmeye çalıştıkları düşünülmektedir.

\section{Sonuç}

Bu çalışmada hipertansiyon hastalarının ilaç uyumunun ve spiritüel iyilik halinin iyi düzeyde olduğu ve hastaların ilaç uyum düzeyi arttıkça spiritüel iyilik halinin de arttığı saptanmıştır. Hipertansiyon hastalarının ilaç kullanımı değerlendirilirken, hastaların ilaç kullanımına yönelik duygu ve tutumlarını etkileyen manevi yönleri de göz önüne alınmalıdır. Bütüncül bir bakım hizmeti sunan hemşirelerin hastaların ilaç uyumunun arttırılmasına yönelik manevi girişimleri de yapması önerilmektedir.

Etik Kurul Onayı: Çalışmanın yapılabilmesi için Aksaray Üniversitesi İnsan Araştırmaları Etik Kurul'undan (2019/36) ve araştırmanın yürütüldüğü kurumdan yazılı izin alınmıştır.

Hakem Değerlendirmesi: Dış bağımsız.

Çıkar Çatışması: Yazarlar arasında herhangi bir çıkar çatışması bulunmamaktadır.

Yazarlık Katkıları: Konsept: G.D.A., C.O.; Dizayn: G.D.A.; Veri Toplama veya Işsleme: G.D.A., C.O.; Analiz veya Yorumlama: G.D.A.; Literatür Arama: G.D.A.,C.O.; Yazan: G.D.A.

\section{Kaynaklar}

1. World Health Organization (WHO). Adherence to Long-Term Therapies: Evidence for Action. Geneva: Switzerland: World Health Organization, 2003. Available at: http://www.who.int/ chp/knowledge/publications/adherence_full_report.pdf. Accessed 21 May, 2019.

2. Tokem Y, Taşcı E, Yılmaz M. Hipertansiyon tanısı olan bireylerin evde hastalık yönetimlerinin incelenmesi. Türk Kardiyol Dern Kardiyovasküler Hemşirelik Dergisi 2013;4:30-40.

3. Hipertansiyon tanı ve tedavi kılavuzu. Türkiye Endokrinoloji ve Metabolizma Derneği, 2018. Erişim adresi:http://www.temd. org.tr/admin/uploads/tbl_gruplar/20180525144116-201805-25tbl_gruplar144115.pdf. Erişim tarihi 30 Haziran 2019.

4. Şengül Ş, Akpolat T, ErdemY, Derici U, Arıcı M, Sindel Ş, et al. Changes in hypertension prevalence, awareness, treatment, and control rates inTurkey from 2003 to 2012. Journal of Hypertension 2016;34:1208-17.

5. Osterberg L, Blaschke T. Adherence to medication. N Engl J Med 2005;353:487-97.

6. Cimete G. Yaşam sonu bakım. İstanbul: Nobel Tıp Kitabevleri; 2002.

7. Cozier YC, Yu J, Wise LA, VanderWeele TJ, Balboni TA, Phil MAA, et al. Religious and spiritual coping and risk of incident hypertension in the black women's health study. Ann Behav Med 2018;52:989-98.

8. Meng $Q$, Xu Y, Shi R, Zhang X, Wang S, Li K, et al. Effect of religion on hypertension in adult Buddhists and residents in China: A cross-sectional study. Sci Rep 2018;8:8203.

9. Kretchy I. Owusu-Daaku F. Samuel Danquah. Spiritual and religious beliefs: do they matter in the medication adherence behaviour of hypertensive patients? Biopsychosoc Med 2013;7:15.

10. Abel WM, Greer DB. Spiritual/religious beliefs \& medication adherence in black women with hypertension. J Christ Nurs 
2017;34:164-9.

11. Silva CF, Borges FR, Avelino CCV, Miarelli AVTC, Vieira GIA, Goyatá SLT. Spirituality and religiosity in patients with systemic arterial hypertension. Rev bioét (Impr.) 2016;24:332-43.

12. Vatansever Ö, Ünsar S. Esansiyel hipertansiyonlu hastaların ilaç tedavisine uyum/öz etkililik düzeylerinin ve etkileyen faktörlerin belirlenmesi. Türk Kardiyol Dern KardiyovaskülerHemşirelikDergisi 2014;5:66-74.

13. Erci B, Elibol M, Aktürk Ü. Hipertansiyon hastalarının tedaviye uyumunu ve yaşam kalitesini etkileyen faktörlerin incelenmesi. FNJN Florence Nightingale Hemşirelik Dergisi 2018;26:7992.

14. Oğuz S, Yanmış S, Yılmaz B, Atman R. Hipertansiyon hastalarının ilaç ve diyet tedavisine uyum düzeyleri. Kardiyovasküler Hemşirelik Dergisi 2019;10:1-7.

15. Tümer A, Subaşı Baybuğa M, Dereli F, Demir Uysal D. Hipertansiyon hastalarının ilaç tedavisine uyum düzeyleri. Kardiyovasküler Hemşirelik Dergisi 2016;7:105-113.

16. Asgedom SW, Atey TM, Desse TA. Antihypertensive medication adherence and associated factors among adult hypertensive patients at Jimma University Specialized Hospital. southwest Ethiopia. BMC Res Notes 2018;11:27.

17. Al-Noumani $H$, Wu JR, Barksdale D, Knafl G, AlKhasawneh E, Sherwood G. Health beliefs and medication adherence in omanis with hypertension. J Cardiovasc Nurs 2018;33:518-26.

18. Nguyen TPL, Schuiling Veninga CCM, Nguyen TBY, Vu TH, Wright EP, Postma MJ. Adherence to hypertension medication: Quantitative and qualitative investigations in a rural Northern Vietnamese community. PLoS ONE 2017;12:e0171203.

19. Ogedegbe G, Mancuso CA, Allegrante JP, Charlson ME. Development and evaluation of medication adherence selfefficacy scale in hypertensive African-American patients. J Clin Epidemiol 2003;56:520-9.
20. Hacıhasanoğlu R. Gözüm S. Çapık C. Validity of the Turkish version of the medication adherence self-efficacy scale-short form in hypertensive patients. Anadolu Kardiyol Derg 2012;12:241-8.

21. Ekşi H, Kardaş S. Spiritüel İyi Oluş: Ölçek Geliştirme ve Geçerliği. Spiritual Psychology and Counseling 2017;2:73-88.

22. Vrijens B, Vincze G, Kristanto P, Urquhart J, Burnier M. Adherence to prescribed antihypertensive drug treatments: longitudinal study of electronically compiled dosing histories. BMJ 2008;336:1114-7.

23. Eğlence $R$, Şimşek N. Hemşirelerin maneviyat ve manevi bakım hakkındaki bilgilerinin değerlendirilmesi. Acıbadem Üniversitesi Sağlık Bilimleri Dergisi 2014;5:48-53.

24. Öz F. İnsan, spiritüel gereksinimler ve hemşirelik. MN Klinik Bilimler\& Doktor 2004; 10:350-8.

25. Koren Elaine M, Papamiditriou C. Spirituality of staff nurses application of modeling and role modeling theory. Holist Nurs Pract 2013;27:37-44.

26. Alvarez JS, Goldraich LA, Nunes AH, Zandavalli MCB, Zandavalli RB, Belli KC,er al. Association between spirituality and adherence to management in outpatients with heart failure. Arq Bras Cardiol 2016;106:491-501.

27. Raghavan R, Ferlic-Stark L, Clarke C, Rungta M, Goodgame $R$. The role of patient religiosity in the evaluation and treatment outcomes for chronic HCV infection. J Relig Health 2013;52:79-90.

28. Oji VO, Hung LC, Abbasgholizadeh R, Hamilton FT, Essien EJ, Nwulia E. Spiritual care may impact mental health and medication adherence in HIV+ populations. HIV/AIDS - Research and Palliative Care 2017;9:101-9.

29. Yosef AR. Health beliefs. Practice, and priorities for health care of Arab Muslims in the United States. J Transcult Nurs 2008;19:284-91. 